\title{
Non-Invasive Colorectal Cancer Screening: An Overview
}

\author{
Melanie Tepus Tung On Yau \\ John van Geest Cancer Research Centre, School of Science and Technology, \\ Nottingham Trent University, Nottingham, UK
}

\section{Keywords}

Colorectal cancer screening · Tumour biomarkers · Diagnostic biomarkers · microRNA · Gut microbiota

\begin{abstract}
Background: Colorectal cancer (CRC) follows a protracted stepwise progression, from benign adenomas to malignant adenocarcinomas. If detected early, $90 \%$ of deaths are preventable. However, CRC is asymptomatic in its early-stage and arises sporadically within the population. Therefore, CRC screening is a public health priority. Summary: Faecal immunochemical test (FIT) is gradually replacing guaiac faecal occult blood test and is now the most commonly used screening tool for CRC screening program globally. However, FIT is still limited by the haemoglobin degradation and the intermittent bleeding patterns, so that one in four CRC cases are still diagnosed in a late stage, leading to poor prognosis. A multi-target stool DNA test (Cologuard, a combination of NDRG4 and BMP3 DNA methylation, KRAS mutations, and haemoglobin) and a plasma SEPT9 DNA methylation test (Epi proColon) are non-invasive tools also approved by the US FDA, but those screening approaches are not cost-effective, and the detection accuracies remain unsatisfactory. In addition to the approved tests, faecal-/bloodbased microRNA and CRC-related gut microbiome screening markers are under development, with work ongoing to find the best combination of molecular biomarkers which maximise the screening sensitivity and specificity. Key Message: Maximising the detection accuracy with a cost-effective approach for non-invasive CRC screening is urgently needed to further reduce the incidence of CRC and associated mortality rates.

(C) 2020 The Author(s)

Published by S. Karger AG, Basel
\end{abstract}




\section{Introduction}

Colorectal cancer (CRC) is the third most common cancer and the second leading cause of cancer-related death worldwide, with over 1.8 million new cases and causing approximately 900,000 deaths in 2018 [1]. The incidence rate varies among countries, with a rate about 3-times higher in developed versus developing countries, while the mortality rate has less variation [1]. The improvement in cancer treatment and the introduction of CRC screening programs have further reduced mortality arising from CRC in developed countries [2-4]. However, the pathogenesis of CRC follows a stepwise progression from benign adenomas to malignant adenocarcinomas, often over a course of 10 years. It is often asymptomatic in its early stages and remains undiagnosed until late stages, where prognosis becomes unfavourable [2]. If detected early, up to $90 \%$ of deaths can be prevented [5]. As a result, a wellplanned public health policy with the development of effective and non-invasive biomarkers could overcome the problem.

\section{Colorectal Cancer Screening Program}

Implementation of CRC screening programs in communities allows early detection of colonic neoplasm(s) to lower the treatment need, morbidity, and mortality [6]. However, CRC screening programs in different countries differ in their approach [7]. These programs can be broadly divided by structured opportunistic and population-based organised (pilot) screening programs (Table 1) [4]. Population-based organised programs have been introduced into the United Kingdom (UK), Croatia, and Hong Kong, with the governments providing a well-organised systematic process of inviting a specific group of individuals for testing. By contrast, structured opportunistic screening programs are implemented on an ad hoc basis, usually through fee-for-service reimbursement of physicians, such as the United States (US) (Table 2).

\section{The United Kingdom}

The UK is a typical example of a population-based organised screening program, where the National Health Service (NHS) has been providing a free-for-charge nationwide Bowel Cancer Screening Program (BCSP) for UK residents since 2006. The BCSP was originally intended for the population between 60 to 69 years of age and recently extended the age range to between age 50 to 74 for their biannual tests. To increase detection accuracy, the screening guidelines have shifted from guaiac faecal occult blood test (gFOBT) to faecal immunochemical test (FIT) since April 2018. Moreover, the NHS also offers a one-off flexible sigmoidoscopy at the age of 55 [8].

\section{Croatia}

The early CRC screening program in Croatia was established in 2007 following recommendations by the European Council in 2003. The program provides a non-invasive gFOBT for the population aged 50 to 74 every 2 years. Positive cases of gFOBT may further be referred for a colonoscopy to confirm the finding [9]. However, the participation rate was below $20 \%$ for 5 years (2007 to 2011), the lowest rate in the European Union [4].

\section{Hong Kong}

The Hong Kong government has a CRC screening program for citizens in the age range of 50 to 74, which is considered an average risk age group. Eligible citizens should receive a FIT every 2 years in this screening program. The guideline from the Department of Health in Hong

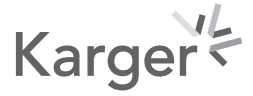


Tumors

Tepus and Yau: Colorectal Cancer Screening

Table 1. Global status of structured and organised colorectal cancer screening by continent in 2018

\begin{tabular}{|c|c|c|c|}
\hline Continent & $\begin{array}{l}\text { Population-based } \\
\text { organised }\end{array}$ & $\begin{array}{l}\text { Population-based } \\
\text { organised pilot }\end{array}$ & $\begin{array}{l}\text { Structured } \\
\text { opportunistic }\end{array}$ \\
\hline Europe & $\begin{array}{l}\text { 1. Belgium } \\
\text { 2. Croatia } \\
\text { 3. Czech Republic } \\
\text { 4. Denmark } \\
\text { 5. Estonia } \\
\text { 6. France } \\
\text { 7. Ireland } \\
\text { 8. Italy } \\
\text { 9. Lithuania } \\
\text { 10. Luxembourg } \\
\text { 11. Malta } \\
\text { 12. Montenegro } \\
\text { 13. The Netherlands } \\
\text { 14. Norway } \\
\text { 15. Poland } \\
\text { 16. Slovenia } \\
\text { 17. Spain } \\
\text { 18. United Kingdom }\end{array}$ & $\begin{array}{l}\text { 1. Austria } \\
\text { 2. Cyprus } \\
\text { 3. Georgia } \\
\text { 4. Hungary } \\
\text { 5. Portugal } \\
\text { 6. Serbia } \\
\text { 7. Sweden } \\
\text { 8. Switzerland }\end{array}$ & $\begin{array}{l}\text { 1. Austria } \\
\text { 2. Germany } \\
\text { 3. Greece } \\
\text { 4. Latvia }\end{array}$ \\
\hline North and Latin America & $\begin{array}{l}\text { 1. Canada } \\
\text { 2. Uruguay }\end{array}$ & $\begin{array}{l}\text { 1. Argentina } \\
\text { 2. Brazil } \\
\text { 3. Chile }\end{array}$ & $\begin{array}{l}\text { 1. USA } \\
\text { 2. Colombia }\end{array}$ \\
\hline Africa & - & - & 1. Morocco \\
\hline Central, West, South Asia & $\begin{array}{l}\text { 1. Israel } \\
\text { 2. UAE }\end{array}$ & $\begin{array}{l}\text { 1. Bahrain } \\
\text { 2. Kuwait } \\
\text { 3. Kazakhstan } \\
\text { 4. Lebanon } \\
\text { 5. Qatar } \\
\text { 6. Saudi Arabia }\end{array}$ & 1. Iran \\
\hline Far East Asia and Oceania & $\begin{array}{l}\text { 1. Taiwan } \\
\text { 2. Korea } \\
\text { 3. Hong Kong } \\
\text { 4. Singapore } \\
\text { 5. Australia } \\
\text { 6. New Zealand }\end{array}$ & $\begin{array}{l}\text { 1. PR China } \\
\text { 2. Thailand }\end{array}$ & $\begin{array}{l}\text { 1. Japan } \\
\text { 2. Malaysia }\end{array}$ \\
\hline
\end{tabular}

Kong also recommended self-funded invasive screening, such as sigmoidoscopy every 5 years or colonoscopy every 10 years [10]. A similar screening program can also be found in Macau and Taiwan $[11,12]$.

\section{The United States}

In the US, the CRC screening program is largely opportunistic, and the guidelines are relying on both government institutions as well as national independent bodies, such as the US Preventive Services Task Force and the American Cancer Society (ACS). These organisations provide their professional guidelines for the choice of CRC screening tests according to the latest prevention and evidence-based medicine [4]. Currently, CRC screening is indicated for the patients aged 50 to 75, although the 2018 ACS guideline 
Table 2. Colorectal cancer screening programs in the selected countries

\begin{tabular}{lllll}
\hline & United States & United Kingdom & $\begin{array}{l}\text { Hong Kong/ } \\
\text { Macau/Taiwan }\end{array}$ & Croatia \\
\hline Screening program & Opportunistic & Population-based & Population-based & Population-based \\
\hline Age & $\begin{array}{l}45 \text { to } 75 \\
76 \text { to 85: consult }\end{array}$ & 60 to 75 & 50 to 75 & 50 to 74 \\
\hline Non-invasive & $\begin{array}{l}\text { Annual gFOBT } \\
\text { Annual FIT } \\
\text { Triennial mt-sDNA }\end{array}$ & Biennial FIT & Biennial FIT & Biennial gFOBT \\
& $\begin{array}{l}\text { CT colonography (every 5 years) } \\
\text { Flexible sigmoidoscopy (every 5 years) } \\
\text { Colonoscopy (every 10 years) }\end{array}$ & $\begin{array}{l}\text { One-off flexible } \\
\text { sigmoidoscopy } \\
\text { for age 55 }\end{array}$ & $\begin{array}{l}\text { Sigmoidoscopy } \\
\text { (every 5 years)* } \\
\text { Colonoscopy } \\
\text { (every 10 years) }\end{array}$ & $\begin{array}{l}\text { Colonoscopy } \\
\text { (when gFOBT } \\
\text { positive) }\end{array}$ \\
\hline
\end{tabular}

gFOBT, guaiac faecal occult blood test; FIT, faecal immunochemical test; mt-sDNA, multi-target faecal-based DNA screening test. * Fee-of-charge service.

Table 3. Clinically available non-invasive CRC screening tools

\begin{tabular}{|c|c|c|c|c|c|c|}
\hline $\begin{array}{l}\text { Screening } \\
\text { tool }\end{array}$ & Sample & Detection target & $\begin{array}{l}\text { Specificity, \% } \\
(95 \% \mathrm{CI}) \\
{[\text { Ref.] }}\end{array}$ & $\begin{array}{l}\text { Sensitivity, \% } \\
(95 \% \mathrm{CI}) \\
{[\text { Ref.] }}\end{array}$ & $\begin{array}{l}\text { Advanced adenoma } \\
\text { sensitivity, \% } \\
\text { (95\% CI) [Ref.] }\end{array}$ & $\begin{array}{l}\text { Cost, USD } \\
\text { [Ref.] }\end{array}$ \\
\hline $\begin{array}{l}\text { mSEPT9 } \\
\text { (Epi proColon) }\end{array}$ & Serum & $\begin{array}{l}\text { SEPT9 DNA } \\
\text { methylation }\end{array}$ & $\begin{array}{l}92(89-94) \\
{[70]}\end{array}$ & $\begin{array}{l}71(67-75) \\
{[70]}\end{array}$ & $\begin{array}{l}11.2(7.2-15.7) \\
{[71]}\end{array}$ & $\begin{array}{l}273-445 \\
{[71]}\end{array}$ \\
\hline $\begin{array}{l}\text { mt-sDNA } \\
\text { (Cologuard) }\end{array}$ & Faeces & $\begin{array}{l}\text { NDRG4 and BMP3 } \\
\text { DNA methylation, } \\
\text { KRAS mutations and } \\
\text { haemoglobin }\end{array}$ & $\begin{array}{l}89.8(88.9-90.7) \\
{[72]}\end{array}$ & $\begin{array}{l}92.3(83-97.5) \\
{[72]}\end{array}$ & $\begin{array}{l}42.4(38.9-46) \\
{[72]}\end{array}$ & $\begin{array}{l}492.72 \\
{[73]}\end{array}$ \\
\hline FIT & Faeces & Haemoglobin & $\begin{array}{l}90^{*} \\
{[74]}\end{array}$ & $\begin{array}{l}78^{*} \\
{[74]}\end{array}$ & $\begin{array}{l}39 * \\
{[74]}\end{array}$ & $\begin{array}{l}20-21.65 \\
{[73,75]}\end{array}$ \\
\hline gFOBT & Faeces & Haemoglobin & $\begin{array}{l}90.0(84.2-93.8) \\
{[76]}\end{array}$ & $\begin{array}{l}62.6(34.9-83.9) \\
{[76]}\end{array}$ & - & $\begin{array}{l}3.31-5 \\
{[71,75]}\end{array}$ \\
\hline
\end{tabular}

* No 95\% CI reported from the meta-analysis. 95\% CI, 95\% confidence interval; gFOBT, guaiac faecal occult blood test; FIT, faecal immunochemical test; mt-sDNA, multi-target stool DNA test; mSEPT9, plasma SEPT9 DNA methylation test.

recommended that screening should begin at the age of 45 and does not recommend CRC screening for anyone over 85 . People in the age range between 76 and 85 should consult their medical providers. The ACS guideline also recommended a regular faecal-based noninvasive examination, such as FIT (every year) and mt-sDNA (every 3 years) [13]. gFOBT is no longer recommended due to the high false-positive rate as well as the dietary and pharmaceutical restrictions [14,15]. The ACS guideline also proposed visual invasive examinations, such as CT colonography (every 5 years), flexible sigmoidoscopy (every 5 years) or colonoscopy (every 10 years) [16]. Although opportunistic screening is effective in reducing CRC-related mortality in the US [17], access to CRC screening is not equal [4]. Residents who are in poverty, uninsured, or underinsured are less likely to undergo regular CRC screening $[18,19]$. 


\section{Approved Colorectal Cancer Screening Tools}

\section{Faecal Occult Blood Test and Faecal Immunochemical Test}

Currently, the most common and low-cost non-invasive faecal tests for CRC screening are gFOBT and FIT (Table 3). Both gFOBT and FIT enable detection of a tiny amount of blood by targeting haemoglobin [20]. Individuals with a positive gFOBT or FIT result may receive a gold-standard, invasive colonoscopy to confirm the results and/or removal of polyp(s). A meta-analysis of four randomised controlled trials revealed that annual or biennial gFOBT screening caused roughly a $16 \%$ reduction in CRC-related mortality with no significant effect on CRC incidence [21]. However, gFOBT is limited by its relatively poor sensitivity in advanced colonic adenoma and also requires repeat screening and dietary restrictions [22]. Thus, it is gradually being replaced by FIT $[23,24]$. FIT has a relatively better detection accuracy and can be quantified, providing a tailored screening approach by optimising the cut-off level [25, 26]. A low cut-off reduces the specificity and requires more follow-up with colonoscopy, but increases the sensitivity to identify more individuals with precancerous polyp(s) $[23,27]$. Further optimisation for FIT to improve detection accuracy is still ongoing, including the formulation of a FIT buffer for haemoglobin stabilisation $[28,29]$, the best haemoglobin detection concentration for automated FIT systems, as well as a single-sample (1-FIT) and two-sample (2-FIT) faecal sample protocol per one specimen [30]. Although improvement in FIT detection is still ongoing, a more accurate non-invasive test is urgently needed. At present, the Food and Drug Administration (FDA) in the US approved two other commercially available CRC tests in clinical use, including the multi-target stool DNA (mt-sDNA) test (Cologuard) and plasma SEPT9 DNA methylation test (Epi proColon) (Table 3).

\section{Multi-Target Stool DNA Test (Cologuard)}

Since colonocytes consistently exfoliate and shed into the lumen of the gastrointestinal tract, molecular alterations in faeces, such as DNA methylations, have been widely investigated [31]. The mt-sDNA screening test (also called Cologuard) is an FDA-approved noninvasive CRC screening tool in 2014, developed by EXACT Sciences Corporation (NASDAQ: EXAS) and Mayo Clinic [32]. The test is Clinical Laboratory Improvement Amendments (CLIA) certified and accredited by the College of American Pathologists [33]. It is designed to detect faeces-based DNA biomarkers with occult haemoglobin. The initial development utilised a pre-commercial 23-marker assay, with subsequent findings that there were 3 broadly informative markers for colorectal neoplasia [34]. Based on the findings, the preliminary version of mt-sDNA utilised NDRG4, BMP3, VIM, and TFP12 genes as DNA methylation targets, with mutant KRAS and faecal haemoglobin. At the threshold of $90 \%$ specificity from the 293 healthy controls, the sensitivities for CRC $(n=252)$ and adenomas $\geq 1 \mathrm{~cm} \mathrm{(} n=133)$ were 85 and $54 \%$, respectively [35]. The size of the tumour correlated to the detection sensitivity, increasing from $54 \%$ in $1 \mathrm{~cm}$ to $92 \%$ in $\geq 4 \mathrm{~cm}$ adenomas [35]. Afterwards, the commercially available, FDA-approved mt-sDNA version 2.0 by the "DeeP-C" study utilised NDRG4 and BMP3 DNA as methylation markers with KRAS mutations plus FIT. The "DeeP-C" prospective study recruited almost ten thousand participants in an average-risk community asymptomatic of CRC [36]. The sensitivity for CRC and precancerous lesions was 92.3 and $42.4 \%$, respectively, and presented a higher sensitivity compared to only one FIT kit at one cut-off (CRC: 73.8\%, $p=0.002$; pre-cancerous lesions: $23.8 \%, p<0.001$ ) [36].

Following the approval, further clinical trials were continued. In the Alaska native cohort ( $n=661$ ) [37], the test presented a sensitivity of $49 \%$ for advanced colorectal neoplasms $(n=92)$ versus $28 \%$ for FIT $(p<0.001)$. The specificity of mt-sDNA was $93 \%$, which is $3 \%$ lower than FIT ( $p=0.034)$ in the subjects in whom no adenomas were detected [37]. Later, 
the mt-sDNA test was applied in frozen samples $(n=1,047)$ from the Netherlands prospective COCOS study for further FIT comparison in advanced colorectal neoplasia $(n=102)$. The mt-sDNA had a sensitivity of $49 \%$ and specificity of $89 \%$, showing better accuracy than FIT, which had a sensitivity of $25 \%$ and specificity of $96 \%[38,39]$. An additional clinical trial at the Netherlands cancer institute is still ongoing [40]. It should be taken into account that a positive test result with no findings on colonoscopy may be due to other causes as NDRG4 and BMP3 methylation can be found from other gastrointestinal diseases such as gastric and pancreatic cancers, although it is rare [41-43].

\section{Plasma SEPT9 DNA Methylation Test (Epi proColon)}

In addition to faeces, DNA methylation can also be determined from blood. The SEPT9 methylation detection in plasma has been evaluated in multiple studies. Epigenomics AG (ECX: FRA) in Germany first implemented the SEPT9 methylation biomarker in Europe in 2008 [44]. Two years later, the commercialised Epi proColon qPCR kit version 1.0 was launched in Europe and later upgraded to version 2.0 [45]. The Chinese Food and Drug Administration and the US FDA approved the Epi proColon kit in 2015 and 2016, respectively. In the prospective "PRESEPT" study, the methylated SEPT9 assay demonstrated a sensitivity of 48\% for CRC (from stages I-IV, 35, 63, 46, and 77\%, respectively) with a specificity of $92 \%$; however, merely $11 \%$ of advanced adenomas were identified [46]. The commercially available kit provides 2 different algorithms, the $2 / 3$ algorithm test has a relatively high true negative rate, while the sensitivity is higher in the $1 / 3$ algorithm [47]. A meta-analysis study published in 2017 including 25 research articles found that the SEPT9 assay is only superior to the FIT in the symptomatic population [48]. Due to its relatively poor sensitivity, the US Preventive Services Task Force and the ACS currently do not include the Epi proColon test in their CRC screening guidelines [49].

\section{Screening Tools under Development}

One of the biggest challenges in early cancer diagnosis and/or prognosis is the lack of reliable biomarkers, leading to several screening tools, such as PreGen-Plus ${ }^{\mathrm{TM}}$ (KRAS, APC, and p53 mutations) [50], ColoSure ${ }^{\mathrm{TM}}$ (VIM methylation), and COLVERA ${ }^{\mathrm{TM}}$ (BCAT1 and IKZF1 methylation) [51], being withdrawn from the market [50,52]. Therefore, developing a low-invasive biomarker that can be easily performed with a clear clinical outcome is necessary. Apart from DNA methylation tests in both faeces and blood samples, other molecular biomarkers are being developed for CRC screening, such as circulating tumour DNA (ctDNA) [53], tumourderived circulating cell (CTC) [54], circular RNA (circRNA) [55], PIWI-interacting RNA (piRNA) [56], microRNA (miRNA) [57-60], and gut microbes (Table 4). Studies relating to miRNA and gut bacteria will further be discussed.

\section{microRNAs Detection in Blood and Faeces}

miRNAs are a class of conserved endogenous, non-coding RNAs with approximately 18-24 nucleotides and play an important role in post-transcriptional regulation of proteincoding gene expression(s) through binding primarily to the 3 '-untranslated region of the target mRNA(s), resulting in mRNA degradation and/or translational repression [61]. Thus, aberrant miRNA expression leads to disease progression and thus can be useful as diagnostic and/or prognostic predictors to human diseases. Until now, numerous research articles have reported that both blood- and faecal-based miRNAs can be utilised as biomarkers for CRC screening. Among them, miR-21 and miR-92a are the highly reported miRNAs for CRC screening [62].

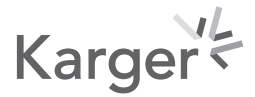




\section{Gastrointestinal Tumors}

Table 4. Selected developing molecular biomarkers for colorectal cancer screening

\begin{tabular}{|c|c|c|c|c|c|c|}
\hline Types & Sample & $\begin{array}{l}\text { Molecular } \\
\text { biomarker(s) }\end{array}$ & $\begin{array}{l}\text { AUC } \\
(95 \% \mathrm{CI})\end{array}$ & $\begin{array}{l}\text { Sensitivity, \% } \\
(95 \% \mathrm{CI})\end{array}$ & $\begin{array}{l}\text { Specificity, \% } \\
(95 \% \mathrm{CI})\end{array}$ & Ref. \\
\hline \multirow[t]{7}{*}{$\begin{array}{l}\text { DNA } \\
\text { methylation }\end{array}$} & Plasma & $\begin{array}{l}\text { APC, MGMT, RASSF } 2 A \text {, } \\
\text { WIF1 }\end{array}$ & 0.927 & 86.5 (81.7-90.8) & $92.1(88.2-95.0)$ & [81] \\
\hline & Plasma & BCAT1, IKZF1 & NA & 66 & 94 & [82] \\
\hline & Serum & $S D C 2$ & NA & 87 & 95.2 & [83] \\
\hline & Plasma cfDNA & LINE-1 & 0.81 & 65.8 & 90 & [84] \\
\hline & \multirow[t]{2}{*}{ Faeces } & \multirow[t]{2}{*}{$N D R G 4$} & T: 0.77 & T: 61 (43-79) & T: 93 (90-97) & \multirow[t]{2}{*}{ [85] } \\
\hline & & & V: NA & V: 53 (39-67) & V: $100(86-100)$ & \\
\hline & Faeces & TFPI2 & NA & $76(60-88)$ & 93 (77-99) & [86] \\
\hline \multirow{2}{*}{$\begin{array}{l}\text { Circulating } \\
\text { tumour DNA }\end{array}$} & \multirow[t]{2}{*}{ Serum cfDNA } & ALU115 & 0.8458 & 69.23 & 99.09 & \multirow[t]{2}{*}{ [87] } \\
\hline & & ALU247/115 & 0.8551 & 73.08 & 97.27 & \\
\hline \multirow{4}{*}{$\begin{array}{l}\text { Circular RNA } \\
\text { (circRNA) }\end{array}$} & Plasma & $91 \mathrm{H}$, PVT1, MEG3 & 0.877 & 82.76 & 78.57 & [88] \\
\hline & Serum & $\begin{array}{l}\text { LOC285194, RP11- } \\
\text { 462C24.1, Nbla12061 }\end{array}$ & $0.79(0.71-0.86)$ & 68.33 & 86.89 & [89] \\
\hline & Whole-blood & NEAT1_v1 & $0.73(0.60-0.83)$ & 56.7 & 83.3 & [90] \\
\hline & Whole-blood & NEAT1_v2 & $0.85(0.73-0.93)$ & 86.6 & 83.3 & {$[90]$} \\
\hline \multirow{4}{*}{$\begin{array}{l}\text { PIWI-interacting } \\
\text { RNA (piRNA) }\end{array}$} & \multirow[t]{4}{*}{ Serum } & \multirow[t]{2}{*}{ piR-5937 } & T: 0.8060 & 71.8 & 72.5 & \multirow[t]{2}{*}[56]{} \\
\hline & & & V: 0.7673 & 73.6 & 65.3 & \\
\hline & & \multirow[t]{2}{*}{ piR-28876 } & T: 0.8065 & 75.3 & 70.0 & \multirow[t]{2}{*}[56]{} \\
\hline & & & V: 0.7074 & 66.0 & 65.3 & \\
\hline \multirow{8}{*}{$\begin{array}{l}\text { microRNA } \\
\text { (miRNA) }\end{array}$} & Plasma & $\operatorname{miR}-92 a$ & 0.885 & 89 & 70 & [91] \\
\hline & Serum & $\operatorname{miR}-210$ & 0.82 & 74.6 & 73.5 & [92] \\
\hline & Plasma & miR-24 & $8.84(0.79-0.89)$ & 78.4 & 83.9 & [93] \\
\hline & Faeces & miR-221 & $0.73(0.68-0.78)$ & $62(55-68)$ & $74(67-80)$ & {$[60]$} \\
\hline & Faeces & miR-20a & $0.73(0.68-0.78)$ & $55(47-62)$ & 82 (76-87) & {$[57]$} \\
\hline & Faeces & miR-135b & 0.79 & $78(69-85)$ & 68 (58-77) & [59] \\
\hline & Faeces & $\begin{array}{l}\text { miR-92a, miR-21, } \\
\text { miR-135b, miR-145, } \\
\text { miR-133a }\end{array}$ & 0.849 & 81 & 80 & {$[94]$} \\
\hline & Saliva & miR-21 & NA & 97 & 91 & [95] \\
\hline \multirow{2}{*}{$\begin{array}{l}\text { Exosomal } \\
\text { microRNA }\end{array}$} & Plasma & $\operatorname{miR}-27 \mathrm{a}$ & $0.87(0.77-0.96)$ & 81.82 & 90.91 & \multirow[t]{2}{*}{ [96] } \\
\hline & Plasma & miR-130a & $0.82(0.73-0.90)$ & 69.32 & 100 & \\
\hline $\begin{array}{l}\text { Tumour-derived } \\
\text { circulating cell }\end{array}$ & Whole-blood & $\begin{array}{l}\text { Circulating endothelial } \\
\text { cell clusters }\end{array}$ & $0.92(0.84-1.00)$ & NA & NA & {$[54]$} \\
\hline \multirow[t]{2}{*}{ Gut microbes } & Faeces & $\begin{array}{l}\text { F. nucleatum, } \\
\text { Parvimonas micra }\end{array}$ & 0.84 & NA & NA & [76] \\
\hline & Faeces & $\begin{array}{l}\text { F. nucleatum, } \\
\text { Clostridium hathewayi, } \\
\text { Lachnoclostridium sp., } \\
\text { Bacteroides clarus, and FIT }\end{array}$ & NA & 93.8 & 81.2 & {$[80]$} \\
\hline
\end{tabular}

95\% CI, 95\% confidence interval; NA, not available; T, training; V, validation; cfDNA, cell-free DNA. 
In a meta-analysis of the blood-based miRNA study, the overall sensitivity and specificity of blood-based miRNAs for CRC is 76\% (95\% CI, 72-80\%) and 76\% (95\% CI, 72-80\%), respectively [63]. The most predictive miRNA was miR-92a, ranging from a sensitivity of $65.5 \%$ to $89 \%$, and from a specificity of $70 \%$ to $82.5 \%$, with the area under the receiver-operating characteristics (AUC) between 0.786 and 0.890 [63]. However, the major shortcoming of using blood-based miRNA for CRC screening is the detection specificity. This is because miRNAs might arise from other cancer(s) [64, 65], depression [66], and virus infection(s) [67, 68]. Therefore, faecal-based miRNA detection may be an alternative option [57, 59, 60, 69]. It has been demonstrated that miRNAs are highly stable short sequences which remain detectable within samples throughout a 72-hour incubation period due to protection from ribonuclease degradation by exosomes [70,71]. A meta-analysis showed that miR-21 is the most reliable miRNA [72]. However, as faeces contain abundant amounts of proteins and DNA from gut microbes, the purity of RNA samples from faeces may determine the result outcomes. As a result, faecal-miRNA detection in combination with FIT is a reliable approach to enhance the detection accuracy. Previous studies indicated that the combination of miR-21 and miR-92a with FIT had a specificity of $96.8 \%$ and sensitivity of $78.4 \%$, while FIT alone only had a specificity of $98.4 \%$ and sensitivity of $66.7 \%$ [73].

\section{Faecal-Based Microbe Detection}

The gut flora habitat has a vast amount of microbes and plays an important role in maintaining our health. Changes in microbiome composition have been linked to multiple diseases including cancer. The study of biomarkers from the gut microbiome has a particular focus on CRC, where clinical use is already on the horizon [74]. It is known that dysbacteriosis alters metabolic activities and induces inflammatory stimuli to the gastrointestinal tract, and eventually induces mutations to colonic cells, thus contributing to the development of the CRC. Among multiple microbial taxonomic markers, intensive research showed that Fusobacterium nucleatum is enriched in tumour neoplasms as well as in faeces from CRC patients [75, 76]. F. nucleatum belongs to the class of asaccharolytic bacteria. Enrichment of $F$. nucleatum in the gut does not only recruit tumour-infiltrating immune cells and induces a pro-inflammatory microenvironment, but also contributes to CRC tumorigenesis through its strong adhesive abilities and invasive effects on epithelial cells [77]. Furthermore, F. nucleatum survives and divides in the hypoxic tumour microenvironment, contributing to the cell proliferation and angiogenesis. A meta-analysis indicated that the use of $F$. nucleatum as a biomarker for CRC screening has a sensitivity of 71\% (95\% CI, 61-79\%) and a specificity of 76\% (95\% CI, 66-84\%), with the AUC of 0.80 (95\% CI, 0.76-0.83); the sensitivity and specificity for advanced colorectal neoplasia is 36\% (95\% CI, 27-46\%) and 73\% (95\% CI, 65-79\%), respectively, with the AUC of 0.60 (95\% CI, 0.56-0.65) [78]. The use of $F$. nucleatum together with FIT may improve the detection accuracy for advanced colorectal neoplasia [79]. A most recent report indicated that the combination of F. nucleatum, Clostridium hathewayi, Lachnoclostridium sp., Bacteroides clarus, and FIT presented a high detection accuracy, with a specificity of $81.2 \%$ and sensitivity of $93.8 \%$ [80].

\section{Conclusion}

CRC is the third most aggressive cancer worldwide with a high mortality rate due to the lack of robust biomarkers. Current CRC screening programs are mostly only available to those above age 50 or 55 , despite the latest guidelines recommending that screening should begin from the age of 45. Although colonoscopy is the gold standard for CRC, it being labourintensive and invasive means that it cannot be applied for everyone. Thus, there is a great 
need for a cost-effective and non-invasive CRC screening test to improve the screening accuracy and acceptability. The use of circulating and/or faecal-based miRNAs, as well as gut bacteria, could be the next generation CRC screening biomarkers.

\section{Disclosure Statement}

The authors have no conflicts of interest to declare.

\section{Funding Sources}

Not available.

\section{Author Contributions}

Conceptualisation and writing of the main text and tables, T.O.Y.; revision and proofreading of the manuscript, M.T. All authors have read and agreed to the published version of the manuscript.

\section{References}

1 Bray F, Ferlay J, Soerjomataram I, Siegel RL, Torre LA, Jemal A. Global cancer statistics 2018: GLOBOCAN estimates of incidence and mortality worldwide for 36 cancers in 185 countries. CA Cancer J Clin. 2018 Nov; 68(6):394-424.

2 Yau TO. Precision treatment in colorectal cancer: now and the future. JGH Open. 2019 Feb;3(5):361-9.

3 Arnold M, Sierra MS, Laversanne M, Soerjomataram I, Jemal A, Bray F. Global patterns and trends in colorectal cancer incidence and mortality. Gut. 2017 Apr;66(4):683-91.

4 Schreuders EH, Ruco A, Rabeneck L, Schoen RE, Sung JJ, Young GP, et al. Colorectal cancer screening: a global overview of existing programmes. Gut. 2015 Oct;64(10):1637-49.

5 Simon K. Colorectal cancer development and advances in screening. Clin Interv Aging. 2016 Jul;11:967-76.

6 Zauber AG, Winawer SJ, O’Brien MJ, Lansdorp-Vogelaar I, van Ballegooijen M, Hankey BF, et al. Colonoscopic polypectomy and long-term prevention of colorectal-cancer deaths. N Engl J Med. 2012 Feb;366(8):687-96.

7 Young GP, Rabeneck L, Winawer SJ. The Global Paradigm Shift in Screening for Colorectal Cancer. Gastroenterology. 2019 Mar;156(4):843-851.e2.

8 Koo S, Neilson LJ, Von Wagner C, Rees CJ. The NHS Bowel Cancer Screening Program: current perspectives on strategies for improvement. Risk Manag Healthc Policy. 2017 Dec;10:177-87.

9 Navarro M, Nicolas A, Ferrandez A, Lanas A. Colorectal cancer population screening programs worldwide in 2016: an update. World J Gastroenterol. 2017 May;23(20):3632-42.

10 Lam TH, Wong KH, Chan KK, Chan MC, Chao DV, Cheung AN, et al.; Cancer Expert Working Group on Cancer Prevention and Screening. Recommendations on prevention and screening for colorectal cancer in Hong Kong. Hong Kong Med J. 2018 Oct;24(5):521-6.

11 Wang YW, Chen HH, Wu MS, Chiu HM; Taiwanese Nationwide Colorectal Cancer Screening Program. Current status and future challenge of population-based organized colorectal cancer screening: lesson from the first decade of Taiwanese program. J Formos Med Assoc. 2018 May;117(5):358-64.

12 Colorectal Cancer Screening Program [Internet]. Serviços Saúde do Gov da Região Adm Espec Macau. [cited 2019 Jun 30]. Available from: https://www.ssm.gov.mo/apps1/coloncancer/en.aspx

13 Wolf AM, Fontham ET, Church TR, Flowers CR, Guerra CE, LaMonte SJ, et al. Colorectal cancer screening for average-risk adults: 2018 guideline update from the American Cancer Society. CA Cancer J Clin. 2018 Jul; 68(4):250-81.

14 Robertson DJ, Lee JK, Boland CR, Dominitz JA, Giardiello FM, Johnson DA, et al. Recommendations on Fecal Immunochemical Testing to Screen for Colorectal Neoplasia: A Consensus Statement by the US Multi-Society Task Force on Colorectal Cancer. Gastroenterology. 2017 Apr;152(5):1217-1237.e3.

15 Bibbins-Domingo K, Grossman DC, Curry SJ, Davidson KW, Epling JW Jr, García FA, et al.; US Preventive Services Task Force. Screening for Colorectal Cancer: US Preventive Services Task Force Recommendation Statement. JAMA. 2016 Jun;315(23):2564-75.

16 American Cancer Society updates its colorectal cancer screening guideline: new recommendation is to start screening at age 45 years. Cancer. 2018 Sep;124(18):3631-2.

17 Sur D, Colceriu M, Sur G, Floca E, Dascal L, Irimie A. Colorectal cancer: evolution of screening strategies. Med Pharm Reports. 2019 Jan;92(1):21-4. https://doi.org/10.15386/cjmed-1104. 
18 Welch HG, Robertson DJ. Colorectal Cancer on the Decline - Why Screening Can't Explain It All. N Engl J Med. 2016 Apr;374(17):1605-7.

19 de Moor JS, Cohen RA, Shapiro JA, Nadel MR, Sabatino SA, Robin Yabroff K, et al. Colorectal cancer screening in the United States: trends from 2008 to 2015 and variation by health insurance coverage. Prev Med. 2018 Jul;112:199-206.

20 Young GP, Symonds EL, Allison JE, Cole SR, Fraser CG, Halloran SP, et al. Advances in Fecal Occult Blood Tests: the FIT revolution. Dig Dis Sci. 2015 Mar;60(3):609-22.

21 Hewitson P, Glasziou P, Watson E, Towler B, Irwig L. Cochrane systematic review of colorectal cancer screening using the fecal occult blood test (hemoccult): an update. Am J Gastroenterol. 2008 Jun;103(6):1541-9.

22 Brenner H, Hoffmeister M, Birkner B, Stock C. Diagnostic performance of guaiac-based fecal occult blood test in routine screening: state-wide analysis from Bavaria, Germany. Am J Gastroenterol. 2014 Mar;109(3):427-35.

23 Hol L, Wilschut JA, van Ballegooijen M, van Vuuren AJ, van der Valk H, Reijerink JC, et al. Screening for colorectal cancer: random comparison of guaiac and immunochemical faecal occult blood testing at different cut-off levels. Br J Cancer. 2009 Apr;100(7):1103-10.

24 van Rossum LG, van Rijn AF, Laheij RJ, van Oijen MG, Fockens P, van Krieken HH, et al. Random comparison of guaiac and immunochemical fecal occult blood tests for colorectal cancer in a screening population. Gastroenterology. 2008 Jul;135(1):82-90.

25 Wilschut JA, Hol L, Dekker E, Jansen JB, Van Leerdam ME, Lansdorp-Vogelaar I, et al. Cost-effectiveness analysis of a quantitative immunochemical test for colorectal cancer screening. Gastroenterology. 2011 Nov; 141(5): 1648-55.e1.

26 Lansdorp-Vogelaar I, van Ballegooijen M, Zauber AG, Habbema JD, Kuipers EJ. Effect of rising chemotherapy costs on the cost savings of colorectal cancer screening. J Natl Cancer Inst. 2009 Oct;101(20):1412-22.

27 Kim DH, Pickhardt PJ, Taylor AJ. Characteristics of advanced adenomas detected at CT colonographic screening: implications for appropriate polyp size thresholds for polypectomy versus surveillance. AJR Am J Roentgenol. 2007 Apr;188(4):940-4.

28 Catomeris P, Baxter NN, Boss SC, Paszat LF, Rabeneck L, Randell E, et al. Effect of Temperature and Time on Fecal Hemoglobin Stability in 5 Fecal Immunochemical Test Methods and One Guaiac Method. Arch Pathol Lab Med. 2018 Jan;142(1):75-82.

29 Grazzini G, Ventura L, Rubeca T, Rapi S, Cellai F, Di Dia PP, et al. Impact of a new sampling buffer on faecal haemoglobin stability in a colorectal cancer screening programme by the faecal immunochemical test. Eur J Cancer Prev. 2017 Jul;26(4):285-91.

30 Liles EG, Perrin N, Rosales AG, Smith DH, Feldstein AC, Mosen DM, et al. Performance of a quantitative fecal immunochemical test for detecting advanced colorectal neoplasia: a prospective cohort study. BMC Cancer. 2018 May;18(1):509.

31 Li B, Gan A, Chen X, Wang X, He W, Zhang X, et al. Diagnostic Performance of DNA Hypermethylation Markers in Peripheral Blood for the Detection of Colorectal Cancer: A Meta-Analysis and Systematic Review. PLoS One. 2016 May;11(5):e0155095.

32 Ahlquist DA. Multi-target stool DNA test: a new high bar for noninvasive screening. Dig Dis Sci. 2015 Mar; 60(3):623-33.

33 Prince M, Lester L, Chiniwala R, Berger B. Multitarget stool DNA tests increases colorectal cancer screening among previously noncompliant Medicare patients. World J Gastroenterol. 2017 Jan;23(3):464-71.

34 Ahlquist DA, Sargent DJ, Loprinzi CL, Levin TR, Rex DK, Ahnen DJ, et al. Stool DNA and occult blood testing for screen detection of colorectal neoplasia. Ann Intern Med. 2008 0ct;149(7):441-50.

35 Ahlquist DA, Zou H, Domanico M, Mahoney DW, Yab TC, Taylor WR, et al. Next-generation stool DNA test accurately detects colorectal cancer and large adenomas. Gastroenterology. 2012 Feb;142(2):248-56.

36 Imperiale TF, Ransohoff DF, Itzkowitz SH, Levin TR, Lavin P, Lidgard GP, et al. Multitarget stool DNA testing for colorectal-cancer screening. N Engl J Med. 2014 Jul;371(2):187-8.

37 Redwood DG, Asay ED, Blake ID, Sacco PE, Christensen CM, Sacco FD, et al. Stool DNA Testing for Screening Detection of Colorectal Neoplasia in Alaska Native People. Mayo Clin Proc. 2016 Jan;91(1):61-70.

38 Dublin Pathology. Dublin Pathology 2015. 8th Joint Meeting of the British Division of the International Academy of Pathology and the Pathological Society of Great Britain \& Ireland, 23-25 June 2015. J Pathol. 2015 Sep;237 Suppl 1:S1-52.

39 Berger BM, Levin B, Hilsden RJ. Multitarget stool DNA for colorectal cancer screening: A review and commentary on the United States Preventive Services Draft Guidelines. World J Gastrointest Oncol. 2016 May;8(5):450-8.

40 van Lanschot MC, Carvalho B, Coupé VM, van Engeland M, Dekker E, Meijer GA. Molecular stool testing as an alternative for surveillance colonoscopy: a cross-sectional cohort study. BMC Cancer. 2017 Feb;17(1):116.

41 Majumder S, Raimondo M, Taylor WR, Yab TC, Berger CK, Dukek BA, et al. Methylated DNA in Pancreatic Juice Distinguishes Patients With Pancreatic Cancer From Controls. Clin Gastroenterol Hepatol. 2020 Mar;18(3): 676-683.e3.

42 Chen X, Yang Y, Liu J, Li B, Xu Y, Li C, et al. NDRG4 hypermethylation is a potential biomarker for diagnosis and prognosis of gastric cancer in Chinese population. Oncotarget. 2017 Jan;8(5):8105-19.

43 Yu C, Hao X, Zhang S, Hu W, Li J, Sun J, et al. Characterization of the prognostic values of the NDRG family in gastric cancer. Therap Adv Gastroenterol. 2019 Jul;12:1756284819858507.

44 Payne SR. From discovery to the clinic: the novel DNA methylation biomarker (m)SEPT9 for the detection of colorectal cancer in blood. Epigenomics. 2010 Aug;2(4):575-85. 
45 Issa IA, Noureddine M. Colorectal cancer screening: an updated review of the available options. World J Gastroenterol. 2017 Jul;23(28):5086-96.

46 Church TR, Wandell M, Lofton-Day C, Mongin SJ, Burger M, Payne SR, et al.; PRESEPT Clinical Study Steering Committee, Investigators and Study Team. Prospective evaluation of methylated SEPT9 in plasma for detection of asymptomatic colorectal cancer. Gut. 2014 Feb;63(2):317-25.

47 Bretthauer M, Kaminski MF, Løberg M, Zauber AG, Regula J, Kuipers EJ, et al.; Nordic-European Initiative on Colorectal Cancer (NordICC) Study Group. Population-Based Colonoscopy Screening for Colorectal Cancer: A Randomized Clinical Trial. JAMA Intern Med. 2016 Jul;176(7):894-902.

48 Song L, Jia J, Peng X, Xiao W, Li Y. The performance of the SEPT9 gene methylation assay and a comparison with other CRC screening tests: A meta-analysis. Sci Rep. 2017 Jun;7(1):3032.

49 Bibbins-Domingo K, Grossman DC, Curry SJ, Davidson KW, Epling JW Jr, García FA, et al.; US Preventive Services Task Force. Screening for Colorectal Cancer: US Preventive Services Task Force Recommendation Statement. JAMA. 2016 Jun;315(23):2564-75.

50 Hamzehzadeh L, Yousefi M, Ghaffari S-H. Colorectal Cancer Screening: A Comprehensive Review to Recent Non-Invasive Methods. Int J Hematol Stem Cell Res. 2017 Jul;11(3):250-61.

51 Symonds EL, Pedersen SK, Murray D, Byrne SE, Hollington P, Rabbitt P, et al. Performance comparison of the methylated BCAT1 / IKZF1 ctDNA test (COLVERA) with the CEA assay for detection of recurrent colorectal cancer. J Clin Oncol. 2019 May;37(15_suppl):3589-3589.

52 Locke WJ, Guanzon D, Ma C, Liew YJ, Duesing KR, Fung KY, et al. DNA Methylation Cancer Biomarkers: translation to the Clinic. Front Genet. 2019 Nov;10:1150.

53 Reinert T, Henriksen TV, Christensen E, Sharma S, Salari R, Sethi H, et al. Analysis of Plasma Cell-Free DNA by Ultradeep Sequencing in Patients With Stages I to III Colorectal Cancer. JAMA Oncol. 2019 May;5(8):1124.

54 Cima I, Kong SL, Sengupta D, Tan IB, Phyo WM, Lee D, et al. Tumor-derived circulating endothelial cell clusters in colorectal cancer. Sci Transl Med. 2016 Jun;8(345):345ra89-345ra89.

55 Pan B, Qin J, Liu X, He B, Wang X, Pan Y, et al. Identification of Serum Exosomal hsa-circ-0004771 as a Novel Diagnostic Biomarker of Colorectal Cancer. Front Genet. 2019 Nov;10:1096.

56 Vychytilova-Faltejskova P, Stitkovcova K, Radova L, Sachlova M, Kosarova Z, Slaba K, et al. Circulating PIWIInteracting RNAs piR-5937 and piR-28876 Are Promising Diagnostic Biomarkers of Colon Cancer. Cancer Epidemiol Biomarkers Prev. 2018 Sep;27(9):1019-28.

57 Yau TO, Wu CW, Tang CM, Chen Y, Fang J, Dong Y, et al. MicroRNA-20a in human faeces as a non-invasive biomarker for colorectal cancer. Oncotarget. 2016 Jan;7(2):1559-68.

58 Yu G, Tang JQ, Tian ML, Li H, Wang X, Wu T, et al. Prognostic values of the miR-17-92 cluster and its paralogs in colon cancer. J Surg Oncol. 2012 Sep;106(3):232-7.

59 Wu CW, Ng SC, Dong Y, Tian L, Ng SS, Leung WW, et al. Identification of microRNA-135b in stool as a potential noninvasive biomarker for colorectal cancer and adenoma. Clin Cancer Res. 2014 Jun;20(11):2994-3002.

60 Yau TO, Wu CW, Dong Y, Tang CM, Ng SS, Chan FK, et al. microRNA-221 and microRNA-18a identification in stool as potential biomarkers for the non-invasive diagnosis of colorectal carcinoma. Br J Cancer. 2014 Oct; 111(9):1765-71.

61 Liz J, Esteller M. IncRNAs and microRNAs with a role in cancer development. Biochim Biophys Acta. 2016 Jan; 1859(1):169-76.

62 Toiyama Y, Okugawa Y, Fleshman J, Richard Boland C, Goel A. MicroRNAs as potential liquid biopsy biomarkers in colorectal cancer: A systematic review. Biochim Biophys Acta Rev Cancer. 2018 Dec;1870(2):274-82.

63 Carter JV, Galbraith NJ, Yang D, Burton JF, Walker SP, Galandiuk S. Blood-based microRNAs as biomarkers for the diagnosis of colorectal cancer: a systematic review and meta-analysis. Br J Cancer. 2017 Mar;116(6):76274.

64 Lamichhane SR, Thachil T, De Ieso P, Gee H, Moss SA, Milic N. Prognostic Role of MicroRNAs in Human NonSmall-Cell Lung Cancer: A Systematic Review and Meta-Analysis. Dis Markers. 2018 Oct;2018:8309015.

65 Ma C, Nguyen HP, Luwor RB, Stylli SS, Gogos A, Paradiso L, et al. A comprehensive meta-analysis of circulation miRNAs in glioma as potential diagnostic biomarker. PLoS One. 2018 Feb;13(2):e0189452.

66 Liu S, Zhang F, Wang X, Shugart YY, Zhao Y, Li X, et al. Diagnostic value of blood-derived microRNAs for schizophrenia: results of a meta-analysis and validation. Sci Rep. 2017 Nov;7(1):15328.

67 Lai FW, Stephenson KB, Mahony J, Lichty BD. Human coronavirus OC43 nucleocapsid protein binds microRNA 9 and potentiates NF- $\mathrm{BB}$ activation. J Virol. 2014 Jan;88(1):54-65.

68 Fiorino S, Bacchi-Reggiani ML, Visani M, Acquaviva G, Fornelli A, Masetti M, et al. MicroRNAs as possible biomarkers for diagnosis and prognosis of hepatitis B- and C-related-hepatocellular-carcinoma. World J Gastroenterol. 2016 Apr;22(15):3907-36.

69 Wu CW, Ng SS, Dong YJ, Ng SC, Leung WW, Lee CW, et al. Detection of miR-92a and miR-21 in stool samples as potential screening biomarkers for colorectal cancer and polyps. Gut. 2012 May;61(5):739-45.

70 Hunter MP, Ismail N, Zhang X, Aguda BD, Lee EJ, Yu L, et al. Detection of microRNA expression in human peripheral blood microvesicles. PLoS One. 2008;3(11):e3694.

71 Mitchell PS, Parkin RK, Kroh EM, Fritz BR, Wyman SK, Pogosova-Agadjanyan EL, et al. Circulating microRNAs as stable blood-based markers for cancer detection. Proc Natl Acad Sci USA. 2008 Jul;105(30): 10513-8.

72 Yau TO, Tang CM, Harriss EK, Dickins B, Polytarchou C. Faecal microRNAs as a non-invasive tool in the diagnosis of colonic adenomas and colorectal cancer: A meta-analysis. Sci Rep. 2019 Jul;9(1):9491. 
73 Kanaoka S, Kuriyama S, Iwaizumi M, Yamada T, Sugimoto M, Osawa S, et al. Potential Usefulness of Fecal Immunochemical Test Plus Fecal MicroRNA Assay As a Marker for Colorectal Cancer Screening. Gastroenterology. 2013 May; 144(5):S-599-600.

74 Gagnière J, Raisch J, Veziant J, Barnich N, Bonnet R, Buc E, et al. Gut microbiota imbalance and colorectal cancer. World J Gastroenterol. 2016 Jan;22(2):501-18.

75 Kwong TN, Wang X, Nakatsu G, Chow TC, Tipoe T, Dai RZ, et al. Association between Bacteremia from Specific Microbes and Subsequent Diagnosis of Colorectal Cancer. Gastroenterology. 2018 Aug;155(2):383-390.e8.

76 Yu J, Feng Q, Wong SH, Zhang D, Liang QY, Qin Y, et al. Metagenomic analysis of faecal microbiome as a tool towards targeted non-invasive biomarkers for colorectal cancer. Gut. 2017 Jan;66(1):70-8.

$77 \mathrm{Wu}$ J, Li Q, Fu X. Fusobacterium nucleatum Contributes to the Carcinogenesis of Colorectal Cancer by Inducing Inflammation and Suppressing Host Immunity. Transl Oncol. 2019 Jun;12(6):846-51.

78 Zhang X, Zhu X, Cao Y, Fang JY, Hong J, Chen H. Fecal Fusobacterium nucleatum for the diagnosis of colorectal tumor: A systematic review and meta-analysis. Cancer Med. 2019 Feb;8(2):480-91.

79 Wong SH, Kwong TN, Chow TC, Luk AK, Dai RZ, Nakatsu G, et al. Quantitation of faecal Fusobacterium improves faecal immunochemical test in detecting advanced colorectal neoplasia. Gut. 2017 Aug;66(8):1441-8.

80 Liang JQ, Li T, Nakatsu G, Chen Y-X, Yau TO, Chu E, et al. A novel faecal Lachnoclostridium marker for the noninvasive diagnosis of colorectal adenoma and cancer. Gut. 2019 Nov;gutjnl-2019-318532.

81 Lee BB, Lee EJ, Jung EH, Chun HK, Chang DK, Song SY, et al. Aberrant methylation of APC, MGMT, RASSF2A, and Wif-1 genes in plasma as a biomarker for early detection of colorectal cancer. Clin Cancer Res. 2009 0ct; 15(19):6185-91.

82 Pedersen SK, Symonds EL, Baker RT, Murray DH, McEvoy A, Van Doorn SC, et al. Evaluation of an assay for methylated BCAT1 and IKZF1 in plasma for detection of colorectal neoplasia. BMC Cancer. 2015 Oct;15(1): 654.

83 Oh T, Kim N, Moon Y, Kim MS, Hoehn BD, Park CH, et al. Genome-wide identification and validation of a novel methylation biomarker, SDC2, for blood-based detection of colorectal cancer. J Mol Diagn. 2013 Jul;15(4): 498-507.

84 Nagai Y, Sunami E, Yamamoto Y, Hata K, Okada S, Murono K, et al. LINE-1 hypomethylation status of circulating cell-free DNA in plasma as a biomarker for colorectal cancer. Oncotarget. 2017 Feb;8(7):11906-16.

85 Melotte V, Lentjes MH, van den Bosch SM, Hellebrekers DM, de Hoon JP, Wouters KA, et al. N-Myc downstreamregulated gene 4 (NDRG4): a candidate tumor suppressor gene and potential biomarker for colorectal cancer. J Natl Cancer Inst. 2009 Jul;101(13):916-27.

86 Glöckner SC, Dhir M, Yi JM, McGarvey KE, Van Neste L, Louwagie J, et al. Methylation of TFPI2 in stool DNA: a potential novel biomarker for the detection of colorectal cancer. Cancer Res. 2009 Jun;69(11):4691-9.

87 Hao TB, Shi W, Shen XJ, Qi J, Wu XH, Wu Y, et al. Circulating cell-free DNA in serum as a biomarker for diagnosis and prognostic prediction of colorectal cancer. Br J Cancer. 2014 Oct;111(8):1482-9.

88 Liu H, Ye D, Chen A, Tan D, Zhang W, Jiang W, et al. A pilot study of new promising non-coding RNA diagnostic biomarkers for early-stage colorectal cancers. Clin Chem Lab Med. 2019 Jun;57(7):1073-83.

89 Wang C, Yu J, Han Y, Li L, Li J, Li T, et al. Long non-coding RNAs LOC285194, RP11-462C24.1 and Nbla12061 in serum provide a new approach for distinguishing patients with colorectal cancer from healthy controls. Oncotarget. 2016 Oct; 7(43):70769-78.

90 Wu Y, Yang L, Zhao J, Li C, Nie J, Liu F, et al. Nuclear-enriched abundant transcript 1 as a diagnostic and prognostic biomarker in colorectal cancer. Mol Cancer. 2015 Nov;14(1):191.

91 Ng EK, Chong WW, Jin H, Lam EK, Shin VY, Yu J, et al. Differential expression of microRNAs in plasma of patients with colorectal cancer: a potential marker for colorectal cancer screening. Gut. 2009 0ct;58(10):1375-81.

92 Wang W, Qu A, Liu W, Liu Y, Zheng G, Du L, et al. Circulating miR-210 as a diagnostic and prognostic biomarker for colorectal cancer. Eur J Cancer Care (Engl). 2017 Jul;26(4):e12448.

93 Fang Z, Tang J, Bai Y, Lin H, You H, Jin H, et al. Plasma levels of microRNA-24, microRNA-320a, and microRNA423-5p are potential biomarkers for colorectal carcinoma. J Exp Clin Cancer Res. 2015 Aug;34(1):86.

94 Liang JQ, Yau TO, Yau TC, Szeto CH, Zhao FS, Chan FK, et al. A Novel Microrna Panel for Non-Invasive Diagnosis and Prognosis of Colorectal Cancer. Gastroenterology. 2019 May;156(6):S-496.

95 Sazanov AA, Kiselyova EV, Zakharenko AA, Romanov MN, Zaraysky MI. Plasma and saliva miR-21 expression in colorectal cancer patients. J Appl Genet. 2017 May;58(2):231-7.

96 Liu X, Pan B, Sun L, Chen X, Zeng K, Hu X, et al. Circulating Exosomal miR-27a and miR-130a Act as Novel Diagnostic and Prognostic Biomarkers of Colorectal Cancer. Cancer Epidemiol Biomarkers Prev. 2018 Jul;27(7): 746-54. 